\title{
Secret Sauce and Snake Oil: Writing Monthly Reports in a Highly Contingent Environment
}

\author{
Clay Spinuzzi \\ The University of Texas at Austin
}

\begin{abstract}
At a search marketing company, each search engine optimization (SEO) specialist writes up to 10 to 12 complex 20-page monthly reports in the first ten business days of each month. These SEO specialists do not consider themselves to be writers, yet they generate these structurally and rhetorically complex reports as a matter of course, while negotiating a constantly changing landscape of a contingent, rapidly changing business sector. Under these conditions, how did the SEO specialists manage to write these reports so quickly and so well? What is the standing set of transformations that they enact in order to develop and produce these reports? And given the multiple contingencies, rapid changes, and high individual discretion at this organization - seemingly a recipe for discohesive practices-how did they maintain and develop this standing set of transformations in order to turn out consistent reports? In this article, I draw on writing, activity, and genre research (WAGR) to examine how Semoptco's SEO specialists produced monthly reports, specifically in terms of their constant networking, audience analysis, and ethos building. Finally, the author draws implications for applying WAGR to knowledge work organizations.
\end{abstract}

\section{Keywords}

WAGR, genre, ethos, audience analysis, reports, networks, knowledge work, contingency 


\section{Introduction}

In 2008, I spent 3 months studying how search engine optimization (SEO) specialists at Semoptco,1 a Web services company, coordinated and shared information. These specialists were not considered "writers" by their bosses, their coworkers, or themselves. And yet every month, each of the six SEO specialists wrote an 18- to 20-page report for each client they handled.

A lot rested on each report: Semoptco wanted to retain and upsell clients, and clients in turn wanted to drive more people to their sites. Remarkably, each SEO specialist produced 10 to 12 such reports within the first ten business days of each month. They used the rest of the month to keep up with the fast-changing SEO landscape, build links to their customers' sites, analyze keyword performance, analyze clients' sites for flaws and opportunities, learn new tools and techniques, and communicate new findings to others. This work was all in addition to the research- and writing-heavy work of launching new clients' campaigns.

These reports varied in content and complexity. On one end, Tier 3 clients received a "report card," a set of simple data tables showing how well each keyword was driving traffic to their site, along with action items for the client and Semoptco to take to improve keyword performance. On the other, Tier 1 clients received additional sections: an executive summary, campaign overview, detailed action items including opportunities, short- and long-term goals and objectives, and deep analysis including comparisons of keyword performance for the three major search engines as well as monthly meetings with the specialist. These reports and meetings demonstrated how well Semoptco was serving the client: how much traffic was being driven to the site and from what referring sites, how much of this traffic was being converted into sales (if applicable), how close keyword performance was to its stated goals. Together, they demonstrated the worth of Semoptco's services to the client, justifying further actions.

Since SEO is a relatively new and highly customized industry with a rapidly changing landscape, specialists often encountered unprecedented issues. Consequently, they sometimes had to explain innovative analyses and argue for innovative courses of action.

Under these conditions, how did the SEO specialists manage to write these reports so quickly and so well? What is the standing set of transformations (Spinuzzi, 2008) that they enact in order to develop and produce these reports? And given the multiple contingencies, rapid changes, and high individual discretion at Semoptco — seemingly a recipe for discohesive practiceshow did they maintain and develop this standing set of transformations in 
order to turn out consistent reports? In this article, I draw on writing, activity, and genre research (WAGR) to examine how Semoptco's SEO specialists produced monthly reports. I conclude with implications for future WAGR studies, especially of knowledge work organizations.

\section{Background}

Search Engine Optimization

"Search engine optimization (SEO) is the process of improving the volume or quality of traffic to a Web site from search engines via 'natural' ('organic' or 'algorithmic') search results” (Anonymous, 2009). Suppose an individual is looking for information, perhaps without knowing exactly what she is looking for. She might enter a few keywords into a search engine (say, "cleaning wine spill” or "hotels near disneyland") and skim through the list of results.

Typically, individuals start at the top, looking at each result to see if it offers the right information, products, or services. The most highly ranked sites-the ones in the first few pages of results-are more likely to secure business. So companies will pay to rise higher in the rankings.

But SEO also has a reputation as "snake oil": the work of shysters and frauds who insert irrelevant keywords, often in invisible text (such as white text on a white background), or who improve site rankings for rare five-word phrases. That is, they have worked to drive traffic to a given site, but not to ensure that the site is actually relevant or useful to the searcher.

In my interview with Stan, the Director of Product Development at Semoptco, he acknowledged this reputation:

And this has been an issue since the late 90s, and some of the most egregious things, where people would go in and put, you know, six pages of white text on white background ... people are hiring people to do that, and getting burned by it.

But, he emphasized, Semoptco did not supply snake oil. Rather, Semoptco offered "a very data-centric approach":

Even our SEO team, which is very content-driven, they still spend a lot of time looking at data to go make decisions and then figure out what happened. I mean, Google changed their ranking algorithm about a month and a half ago. And we collect data every day for somewhere between 5 and 50 keywords for our clients to say "how are you ranking?" We saw about three quarters of them go up over two days. In some cases, it was a spot or two. In some cases, it was 10, 15, 30 spots. . . . 
We've changed a lot of techniques we're using ... over the last nine months, and it was great to see that ... completely objective proof point that those things had kind of, had done the addition.

He characterized this replicable, evidence-based analytical approach as Semoptco's "secret sauce": something genuine and reliable and measurable, something that Semoptco could communicate clearly to clients through monthly reports. Therefore those monthly reports included "report cards" that specified the methods Semoptco used and their results over the entire campaign's history. Semoptco could be trusted because it had turned SEO into a methodical, well-managed, data-driven business. Semoptco's workers were intensely aware that they had to build trust and authority — ethos —in this complex, contingent, ever-changing business, primarily through the monthly reports.

The business of SEO is audience analysis (cf. Killoran, 2009). What people have already come to the client's site, and what people should come there? Which keywords will bring the right people to the right site, connect the right customers to the right services? But as with any form of audience analysis, this business was inherently full of contingencies. What Google gives, Google can also take away: search engines often tweaked their algorithms, changing the rankings to combat "snake oil" techniques. Other SEO companies were also at work, optimizing their clients' sites and perturbing the rankings. News items could unpredictably crowd the rankings, pushing down results. The clients themselves were unpredictable: sometimes slow or negligent in implementing Semoptco's recommendations on their own site. These and other contingencies, from multiple directions, made Semoptco's business inherently complex, inherently fast-moving, requiring rapid response and a high degree of autonomy from its SEO specialists. They had to collaborate and plan effectively, demonstrating contingencies and their effective responses through monthly reports. These reports, then, had to be structurally and rhetorically complex.

\section{WAGR}

We can approach the SEO specialists' cyclical activity with a set of theoretical tools from writing, activity, and genre research (WAGR; see Russell, 2009). But we have to be cautious about doing so. As we'll see below, WAGR has traditionally been applied to less contingent, more slowly developing activities, and its conceptual tools and accounts have been adjusted for those sorts of activities.

Genre: an instantiated solution. In WAGR, genres are understood as "typified rhetorical actions based in recurrent situations" (Miller, 1984, p. 31), and thus as a residue of past problem-solving (Spinuzzi, 2003, pp. 40-47). 
They represent a set of rhetorical habits or moves that have been applied to a rhetorical situation in the past, have worked, and are thus mobilized again for similar rhetorical problems (Russell, 1997a, p. 515). In being mobilized, they present a tradition or frame for recurrent actions (Russell, 2010). These typified actions are "stabilized-for-now" (Schryer, 1993). As Russell puts it, "a genre is the ongoing use of certain material tools (marks, in the case of written genres) in certain ways that worked once and might work again, a typified, tool-mediated response to conditions recognized by participants as recurring” (2009, p. 43). (For broad surveys of WAGR, see Russell, 1997b; Schryer \& Spoel, 2005.) Genres, that is, develop through repeated cycles in which they progressively orient (or reorient) to the repeated situations to which they respond.

As they develop by reorienting in these repeated cycles, genres come to embody a given logic or tradition: a frame within which activity is interpreted. For instance, Bazerman describes how the experimental article slowly developed over centuries to fix assumptions about argument and proof in science to the extent that writing an experimental article properly entails using a particular understanding of experiments (1988). Sometimes, these genres introduce logics that contrast with others in the activity. For instance, Propen and Schuster (2010) describe how victims of crime write Victim Impact Statements to be read in a courtroom before judges sentence the convicts. This relatively new genre, which is in practice taught to the victims by advocates, embodies a frame in sharp contrast to the legal frame embodied by other, generally older courtroom genres; it "creates a bridge between public policy ... and internal institutional activity systems such as those of the sentencing hearing that happens within the courtroom” (p. 10).

Genre assemblage: a collectively oriented set of solutions. As Propen and Schuster's study suggests, genres are rarely deployed alone: They interact in genre assemblages to collectively address complex cyclical activities (see Spinuzzi, 2004 for a review of work on genre assemblages). These many genres shape the cyclical activity within which they are mobilized. Russell argues, "The object of activity can be seen to attain its stability, reproduction, and continuity through genres, the mutual recognition necessary for joint action to occur over time” (2009, p. 45). Yet since these genres may have developed in different activities, they may embody contrasting frames. The openly advocative Victim Impact Statements described by Propen and Schuster, for instance, contrasted with impartial legal genres such as sentencing guidelines, and judges expressed conflict as they tried to reconcile these frames (see also Schryer et al., 2009; Spinuzzi, 2003). In such situations, we may see clashes in genres due to their different orientations, leading to rapid development 
and hybridization in some genres in the assemblage as they collectively reorient.

Regularization and regulation: a dimension of stability in solutions. Alone and in assemblages, genres often function to regulate recurrent activities as they provide consistent frames and consistent responses to recurrent situations. But they also provide ways to improvise to address new issues and contingencies. As Schryer and Spoel (2005) argue, "Regulated resources refer to knowledge, skills, and language behaviors that are recognized and required by a field or profession. Regularized resources, on the other hand, refer to strategies that emerge from practice situations and are more tacit” (p. 250). Both tendencies exist in genres. For instance, Schryer, Lingard, \& Spafford (2007) examine case presentations by health care students, arguing that genre includes not only replicable structures but also "regularized improvisations" (p. 26). They argue that "Genres are constellations of regulated and regularized improvisational strategies triggered by the interaction between individual socialization, or habitus, and an organization or field” (p. 31; cf. Winsor, 2007; Teston, 2009; Gygi \& Zachry, 2010). Regulated genres explicitly enforce an orientation; regularized genres tend to implicitly support it (although they can also introduce very different orientations, often inherited from other activities from which they are drawn).

Regulated genres are often constructed through reuse. As Swarts argues, in knowledge workplaces, writers can easily reuse content, leading to hybrid utterances and accommodating "distribution and coordination that are more ad hoc and spread out over time and space” (2010, p. 129). “Thus, chunks of recycled content keep voices mobile and stable and combinable with other chunks” (p. 132; cf. Mirel, 1996). In reuse, Swarts argues, the act of selecting and arranging chunks to reuse is itself rhetorical.

Standing sets of transformations: a way to string together solutions. Finally, assemblages of regulated and regularized genres often constitute standing sets of transformations, in which information is represented and transformed in subsequent genres. For instance, Spinuzzi (2008) describes how an order for telephone service is instantiated in multiple genres and interactions, each of which transforms components of the order in relatively stable, predictable ways (pp. 149-156; cf. Devitt, 1991). Each genre might have its own frame, set of problems to address, and balance between regulated and regularized transformations. In a standing set of transformations, genres might develop in concert, anchored by their shared orientation to the cyclical activity.

Genre development: how solutions are collectively reoriented. Traditionally, WAGR has examined genre development as a way to reorient one or several genres toward a changing cyclical activity. Often, this reorientation is a slow, 
gradual process (e.g., Bazerman, 1988; Devitt, 1991; Miller, 1984). Sometimes, it involves rapid development: in response to major changes in the cyclical activity (e.g., Russell, 1997a; Spinuzzi, 2008) or in response to clashes in genres' orientations or logic (e.g., Gygi \& Zachry, 2010; Propen \& Schuster, 2010; Spinuzzi, 2003). In these cases, genres have a chance to be "digested" in the activity (to borrow an image from Bakhtin, 1986): to collectively reconcile and reorient themselves, often under the tension of regulative genres.

But how can these genres be collectively reoriented under the conditions we find at Semoptco? There, reorientation is rapid, highly contingent, and conducted with a high degree of autonomy. Under these conditions, the characteristics that make genre so powerfully regulative also would seem to make it vulnerable to discohesion. How can genres develop? How can they settle into regularized, let alone regulated, sets of transformations when the situations to which they respond change so rapidly?

\section{Method}

This qualitative case study was approved by the institutional review board at the author's institution. Based on Smagorinsky's (2008) suggestions for developing the methods section, I describe the research questions; discuss the site and the industry; describe the participants; and describe the data collection, reduction, and analysis procedures.

\section{Research Questions}

I sought to answer the following research questions:

Research Question 1: How do Semoptco’s workers produce monthly reports? What tools and texts do they use?

Research Question 2: How do they share information and procedures as they produce reports?

Research Question 3: How do they ensure that the reports address critical rhetorical concerns such as audience analysis and ethos?

The Site and the Industry

During the study, Semoptco employed about 40 account managers and specialists, 6 of whom were SEO specialists. Semoptco's objective was not to simply drive traffic-if it were, Semoptco could simply embed names of celebrities and terms for pornography, as unscrupulous "snake oil salesmen" do. Rather, it was to drive up conversions, visits that turned into transactions. Semoptco offered four basic services: SEO, Paid Search, Display Advertising, 
and Web site Effectiveness Strategy and Consulting. Here, I focus on SEO, in which specialists select the right keywords to reach the customer, then optimize for those keywords; their measures include (a) analyzing keyword performance, (b) advising the client on Web site revisions and additions, and (c) building links that point to the client's site.

\section{Participants}

Study participants included the director of product services, 3 of the 6 Natural Search (SEO) specialists, and 1 of the 3 account managers. All names are pseudonyms.

- Stan, the director of product services, had been at Semoptco for about a year at the beginning of the study. He had worked for similar companies. Stan had a master's degree in information architecture. - Daria, a senior specialist in Natural Search, has worked at Semoptco for just over a year. This was her second job after graduating with a liberal arts degree and a master's degree in information.

- Luis, a senior specialist in Natural Search, had worked at Semoptco for 2 years, initially as an intern while he finished his bachelor's degree in advertising. He had been promoted to senior specialist just before our first interview.

- Carl, a specialist in Natural Search, had worked for Semoptco for 6 months at the time of the first interview. He had apprenticed with Luis during this time. Before then, he had graduated with a history degree from a liberal arts college, then worked a series of jobs including Americorps and quality assurance at a videogame developer.

- Stacy, an account manager, had worked at Semoptco for 7 months at the time of the first interview. She had held similar positions at PR agencies, where she "did tech PR," but had not worked at a search marketing firm before Semoptco. She had a bachelor's degree in public relations.

\section{Data Collection}

Data collection spanned September-November 2008, with a follow-up interview with Stan in August 2009. To develop a rich qualitative understanding of how the participants conducted their work and the genres and media they used, I chose the following qualitative ethnographic methods: Site interviews. I conducted one 40-minute semistructured interview with Stan in September 2008 before contacting the other participants, then a 30-minute follow-up interview in August 2009 (Appendix B). 
Preobservational interviews. I conducted one short (20-30 minute) semistructured interview with Daria, with Stacy, and with Luis and Carl (as a pair) in September 2008 to collect information about their professional biography and history with project management, collaboration, and related tools and practices. (Appendix C).

Naturalistic observations. I conducted three 1-hour observations of Daria, Luis, Carl, and Stacy in October-November 2008. I conducted clusters of observations at different times of the month. During observations, I took detailed field notes that focused on participants'

- work environment, particularly texts.

- interactions with others, including fellow workers and clients. When possible, I copied spoken and written interactions into the field notes verbatim; when not, I summarized and paraphrased.

- interactions with texts, broadly defined as symbolic inscriptions. Interactions with texts included writing, reading, annotating and highlighting, juxtaposing, stacking and arranging, and posting. - movements from one space to another, along with any artifacts they took with them and artifacts they used in each space.

Postobservational interviews. I conducted individual, semi-structured interviews with Stacy, Luis, and Carl immediately after all but one observation, and with Daria after all observations (average 30 minutes; see Appendix D). These interviews focused on how the participants interpreted their own and others' actions during the observation; elicited contextual insights about the texts and procedures I had observed, particularly as they related to work cycles; and confirmed or disconfirmed my understanding of key events in the observation.

Artifact collection. I collected artifacts from Daria, Luis, Carl, and Stacy's workspaces that were related to project management, collaboration, information sharing, teamwork, and training. Artifacts included

- photos of each participant's work environment and any environmental texts (such as posted materials).

- copies or photos of project lists, to-do lists, reports, and marketing collateral.

In all, I collected 12 documents and 22 photos.

To ensure privacy of others, participants redacted artifacts as appropriate before turning them over to me. Consequently, although I was able to observe several participants writing reports, I was allowed to keep only two heavily 
redacted copies.

See Appendix E for a summary of data collected.

Data Storage, Coding, and Reduction

After collecting the data, I transcribed all field notes and paraphrased and partially transcribed interviews.

Field notes. I transcribed these as they were written, with paragraph breaks representing distinct actions or speaking turns within observations. In all, I generated 1,381 observation entries (paragraph-separated units).

Interviews. I initially paraphrased these, then transcribed parts that were critical to the emerging analysis. Paragraph breaks represented changes in speakers. In all, I generated 613 interview entries (paragraph-separated units).

I then placed all data in a relational database, with tables for participants, observations, interviews, and artifacts. I created summary characterizations for entries in each data type (cf. Miles \& Huberman, 1994, pp. 54-55).

Coding. Coding was nonexclusive: Each datum could be assigned multiple codes. I coded entries using the following procedures.

Starter codes. I began coding deductively, using descriptive starter codes (Miles \& Huberman, 1994, pp. 57-58): Time/Project Management, Understanding, Relationships, Strategy, and Training (based on Spinuzzi, 2008, chap. 6).

Open coding. In open coding (Corbin \& Strauss, 2008), I inductively identified recurrent themes, defined codes based on them, then checked these codes deductively based on these definitions. I coded for tool and text use and production; search use; types of interactions; teams; and indications of planning and cycles.

- Basing open codes on preobservation interview questions. I first developed open codes based on specific issues discussed during preobservation interviews, then applied them to related data in the other data types.

- Autocoding open codes. For codes related to texts and tools, I initially auto-coded (applied codes based on keywords in the observation notes and interview text), then added codes to applicable entries that did not share the keywords. I interspersed autocoding with developing open codes.

- Developing open codes. I treated open codes as emergent and recursive (Corbin \& Strauss, 2008): Information in one set of data might yield hypotheses that I could then test by coding other datasets. 
Axial coding. Finally, I performed axial coding, loosely based on Corbin and Strauss (2008), to draw connections across starter and open codes. To develop axial codes, I looked for codes that appeared together frequently, then used a single code to articulate the relationship among them, developing a specific description for that code. I then recoded all data for those axial codes, applying it to each piece of data that fit the description.

Data reduction. In identifying recurrent themes, coding also allowed me to reduce the data by focusing on heavily coded data and on data related to key themes.

Appendix A lists codes and examples.

\section{Data Analysis}

To analyze the data, I followed these procedures:

Triangulating. I tested relationships between codes by examining whether they were supported by multiple data sources. I triangulated in the following ways:

- Across data types, same incident. This triangulation involved examining how the same incident was represented in two or more data types, such as an observation and the corresponding post-observational interview.

- Across participants. This triangulation involved examining how the same phenomenon was represented in two or more participants'

data. This form of triangulation allowed me to confirm how idiosyncratic or shared that phenomenon was.

- Across visits. This triangulation involved examining how different actions were taken at different points of the work cycle.

In the analysis below, I draw on all three kinds of triangulation; each incident, phenomenon, and action is supported by correspondingly triangulated data.

Conducting member checks. After drafting the completed analysis, I shared it with the participants for comments in October-November 2009. Participants offered no critical comments.

\section{Findings}

Specialists constantly adapted to contingencies. These contingencies included constant customization to collaboratively address the unique constraints of each client's industry and the new tools and analytics available for SEO; constant boundary-crossing to better analyze each client's industry, its target 
audiences, and what keywords would draw them; and constant ethos-building through results demonstrating that Semoptco's specialists were competent, honest, and accurate. Semoptco accomplished all of these through a standing set of transformations that produces the monthly report.

Below, I'll first discuss Semoptco's projects and what they accomplish. Then I'll detail how it handled the three kinds of contingencies. Throughout, I source data to Appendix E's tables.

\section{Semoptco's Projects: Launch and Maintenance}

Semoptco had to first launch clients, which involved defining their goals and developing a plan of action to meet them. Then they had to maintain those clients, continuing to make progress on long-term goals and adjusting when necessary. Both phases involved extended sets of texts, some of which were shared across phases. Let's briefly look at each phase.

\section{Launch Mode}

Launching a client looked somewhat like traditional project management (Duncan, 1996) and, as discussed below, it drew on some of the heavily coordinative genres that are associated with project management. When a client first comes to Semoptco, Stan told me, it might have a history with "snake oil" SEOs that makes it more cautious (I1.1). Semoptco typically extracted the client's verbal commitment to stick with Semoptco for at least 6 months, since that's how long it typically takes for an SEO campaign to show results. Similarly, if a client paused or terminated its SEO campaign, results degraded over time.

At Semoptco, the CEO selected a project team for each client (I3.1; I4.1/5.1),pairing an account manager with an SEO specialist. The project team then produced texts associated with the launch. Initially, they would present the client with a launch plan, based on a standard template, showing a few milestones for the client and the project team to accomplish by launch (I2.1, I3.1, I4.1/5.1, A15, A16, and A18). Milestones included "client research," "nonkeyword specific link building," "Web analysis," "recommended SEO keywords," "keyword specific link building," "on page recommendations," and "competitive analysis.” The launch process typically took 4 weeks, and milestones were relatively fixed (I3.1).

\section{Maintenance Mode}

Once the campaign was launched, it went into maintenance mode (I4.1/5.1). Specialists worked toward long-term objectives related to performance metrics, but without fixed milestones. Instead, they maintained campaigns 
according to weekly, monthly, and sometimes yearly cycles. Maintenance mode was routinized, but not dormant; all parties had to actively problem solve to improve each campaign.

For the specialists, maintenance mode involved three main tasks: writing monthly reports for clients, meeting with clients (either in person or in conference calls) to report results, and building links (A18). In my initial observations in early October, reporting and meetings took the first 2 weeks of the month, with link-building taking the second 2 weeks. But by late October, Luis told me, "the first ten days are getting shorter due to business tools" such as BRILLIANCE, a system developed in-house to automatically track analytics, metrics, and notes on clients' Web sites (I4.4). Carl confirmed that at this point, "that first third of the month is reporting, the middle third is meetings with the clients about those reports ... that last third is even more 'do whatever you need to do"' (I5.3).

Luis clarified that the first 3 days of reporting were dedicated to Tier 1 clients (I4.3). But beyond monthly deadlines, individual specialists structured their own time. As Daria put it, "For the most part, even just with client stuff, it's kind of expected-okay, here's what you need to have done by the end of the month. You've got your timeline, you know this client's done with launching, so here's how much we need to spend on links, here's how many of these types of links we need to build” (I2.1; cf. I5.3). SEO specialists exercised considerable operational autonomy, managing their own time, identifying their own tasks, and communicating their own accomplishments.

From the account manager's perspective, the monthly cycle involved ensuring clients received reports and monitoring progress. As Stacy told me, "Once a client gets in maintenance mode, it's less contact and moreevery few weeks, try to touch base on things” (I3.1). She had to check the status of not only the specialists' work but also the clients': for instance, after I observed her prodding one client via email for feedback, she said, "the marcomm [marketing communication] managers aren't super involved, and so they will, like, forget that we exist for weeks and months at a time." (O3.3, I3.3).

Account managers sometimes needed to frame monthly reports as well, explaining Semoptco's services and their value. In one observation, Stacy received a specialist's report which recommended increasing the budget for buying links. Stacy drafted an email to the client arguing for increasing the link-buying budget as well as increasing the management fee (O3.4) something that would result in more Semoptco revenue, yes, but also in better SEO.

Account managers also vetted reports for clients. As Stacy explained after 
one observation, specialists sometimes wrote these reports to the client, sometimes to the account manager, "so they each need a different amount of editing” (I3.4). Specialists sometimes used specialized language that the account manager had to translate for clients. But account managers also had to look for unusual variations in the reports. When reading one report, for instance, she noted language that "didn't look right," so she consulted with more experienced account managers (O3.4, I3.4).

In the launch process, then, project management was quite minimal, and in maintenance mode, it was nonexistent-something that may be surprising, given the work's complexity, but that addresses the work's many contingencies. Contingent work meant that regulated coordinative practices and genres would be too static to coordinate the work well. Instead, Semoptco operated by pushing discretion and autonomy to the level of the specialists while making sure those specialists could communicate status to each other. Semoptco's launch and maintenance modes established a standing set of transformations, enabled largely through a flexible assemblage of genres that allowed its workers considerable discretion in reacting to challenges.

\section{Report Writing as a Standing Set of Transformations}

So let's examine that standing set of transformations. Specialists assembled reports, to some extent automatically, from information they entered into BRILLIANCE — but that oversimplifies the many acts of reading and writing involved. For instance, in one observation (O4.2), Luis heavily highlighted and annotated the previous month's report, then entered notes from it into BRILLIANCE; these notes would become sections of the current month's report. lso gathered text from client emails, instant messages and face-to-face conversations with Carl, a spreadsheet he used to track his own projects, the Wiki Answers site, and an autogenerated draft of this month's report (see left side of Figure 1). Like other specialists, Luis didn't consider himself a writer, and from his perspective, he wasn't "writing” a 20-page report: he was analyzing Web site traffic, making notes, and double-checking emails. Nevertheless, these actions generated reports that connected clients' goals, Semoptco's actions, keyword results, and other information into a structurally and rhetorically complex argument. 


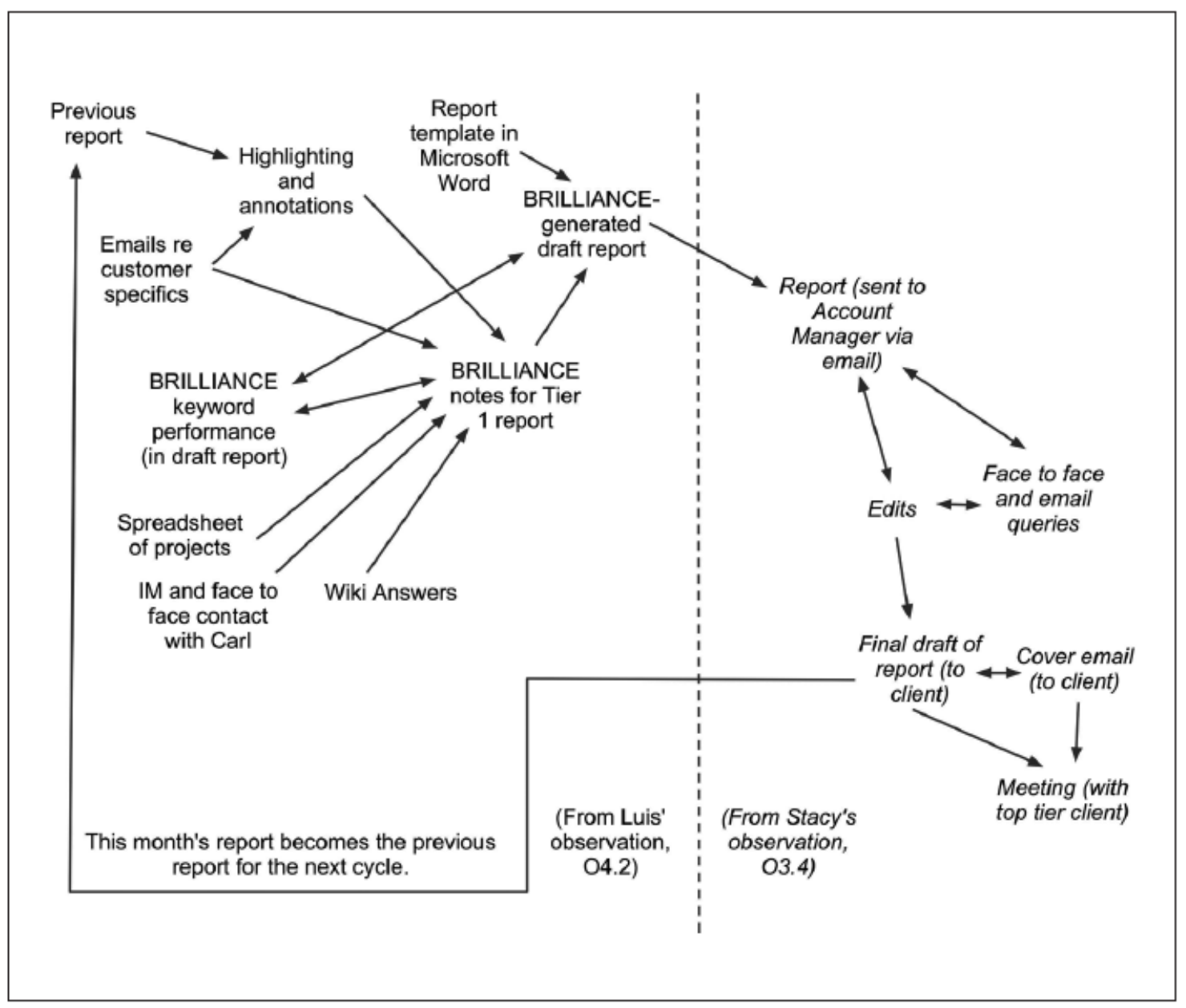

Figure I. Generating a monthly report at Semoptco

As the right half of Figure 1 shows, the completed report was then emailed to the account manager for that client, who sometimes had to edit it. Here, Stacy (O3.4) had to review a report, ask other account managers if they had seen similar language, edit the wording so that her clients could understand it, then email the report to the client with some explanatory text.

Finally, as Figure 1 shows, top-tier clients also received a meeting. And then the document would become the previous report for the next cycle. Figure 1 describes a standing set of transformations involving many texts, some of which were automated or heavily regulated (keyword performance tables), some regularized (highlighting and annotations), some coordinative (projects spreadsheet), some specific to that project and cycle (specific emails, IMs). Some were innovated in a given cycle, then instantiated in the resulting report.

Although I've separated launch and maintenance modes here, specialists 
and account managers had to attend to both modes simultaneously: each one could be involved with multiple launches and multiple maintenance projects at the same time. Sometimes these cycles collide, with maintenance meetings, launch deliverables, and link building happening at the same time (I4.4).

So what challenges did Semoptco face as they marshalled all of these textual resources to generate their analytical reports? Three emerged: constant customization, constant boundary-crossing, and constant ethos-building.

\section{Semoptco's Flexibility: Constant Customization}

"Do you think campaigns usually go in the same track," I asked Stacy, "or is each one a unique situation?” Without hesitation, she responded, “They're all very different” (I3.1). This point was repeated, with many examples, by Daria, Luis, and Carl. Each campaign, each client, each launch, and each iteration of the monthly maintenance cycle was considered unique. For some, specialists and account managers developed innovations. But what made these situations unique? How did Semoptco's specialists and account managers collaboratively solve them and produce their reports?

\section{The Challenges of Customization}

Semoptco had established firm launch timelines, three tiers of reports, and templates for its monthly reports and other deliverables-all measures that we might expect would lead to greater standardization and inflexibility, not greater flexibility. In fact, Daria stated in her preobservation interview that when she began training new hires, her goal was:

to make it a really structured process with lots of documents. And I have documents. But . . . you're never sure what you're going to be doing the next day. So the structure ... just hasn't been able to happen as much as I would like it to. So really, it's been a lot of-at first, learning, reading, looking at examples of the documents, looking at examples of our deliverables. And then-pretty much mentoring, letting people just do it and help them as they go and let them get practice at it [my emphasis]. (I2.1)

Luis, who had worked at Semoptco longer, found this structure to be a starting place: "we like follow the template, and then ... customize it according to the client, which we do very often" (I4.4).

Customization for specific clients turned out to be a major contingency driving innovation at work. For instance, Daria and Luis both innovated new documents or new variations of documents based on clients' contingencies. 
During one observation (O4.4), Luis was working on the competitive analysis for a client whose campaign was about to launch. As Luis reviewed the competitors the client had identified, he concluded that these were not the best online competitors to target. He identified better competitors, then developed a table to demonstrate that this set was superior. Later, he explained that

I didn't have planned to create this other extra document to show the client, why are we picking up these competitors. Uh, sometimes ... they understand pretty easy, it's not required. But this time the client really doesn't understand why. So we have to show him, like, another kind of deliverable to make him understand why ... [my emphasis] (I4.4)

Similarly, while examining analytics for one client (O2.2), Daria was trying to determine whether the client's monthly email blasts were causing traffic surges. She spent about half an hour pasting numbers into a spreadsheet from different sources, then generating graphs with titles such as "Daily SEO Revenue vs. Email Blast Dates.” Later, she told me that these graphs were innovations responding to a unique situation. She would improvise such graphs "probably only for big important clients" (I2.2).

"You pay for bigger customization," Luis told me (I4.1/5.1), and indeed, Tier 1 clients received more customized solutions. For instance, Daria reported that one of the biggest clients received annual reports as well as monthly ones: "if they want it, they'll get it" (I2.3). Similarly, Stacy developed a spreadsheet for keeping track of contacts at a large client (O3.3, I3.3), and Carl tracked additional analytics for a client that requested them (O5.4, I5.4).

Customization in response to search engine changes was less frequent but exceedingly important: even small algorithm changes can roil search engine results. Semoptco had to detect these changes and adjust accordingly, keeping clients informed. For instance, in one report, Luis wrote that "[Semoptco] noticed negative fluctuations for targeted keywords within MSN rankings” and discussed how to address them (A19). Constant search engine changes led Semoptco to hire more flexible, self-motivated specialists: "Google . . . starts evolving and you have to evolve with it,” Daria explained (I2.1).

Customization by offloading problem-solving. Semoptco's workers actively changed their work itself by constantly routinizing and offloading tasks to regulated genres. Workers learned a routine just long enough to stabilize it in a genre and turn to the next challenge. Today's innovations become tomorrow's regulated, automated solutions and templates. By examining and offloading their processes, workers freed up more time to conduct work they couldn’t offload, such as in-depth analysis. 
At Semoptco, this constant offloading took at least three forms:

- Internally refining and automating resources. Semoptco's workers refined internal resources. For instance, Semoptco had recently tracked links with "a lot of spreadsheets with macros pulling into other spreadsheets" but "a lot of that has migrated to BRILLIANCE, so we don't have to mess with that anymore," Daria reported (I2.1; cf. I1.1). BRILLIANCE also autogathered information on specified links and tracked client expenses; it became a rolling context for any given project, context shared by specialists and account managers (I3.1). Daria even used BRILLIANCE's data on paid search (a separate service) to generate ideas about selecting proper keywords (I2.2). Another part of BRILLIANCE's work was to autogenerate key components of the templated reports. Eventually, Luis told me, Semoptco planned to serve reports directly to clients through BRILLIANCE rather than sending documents (I4.3). Beyond BRILLIANCE, Semoptco's templates offloaded the work of developing deliverables from scratch.

- Internally developing new resources. Semoptco's development team also created internal tools for automating work (I1.1; O2.4; I2.4). During one observation, specialists talked excitedly about a tool under development that would let them post to several social bookmarking sites simultaneously, using multiple login names, and simultaneously update BRILLIANCE. "The interns will love this!" one specialist enthused (O5.4). But specialists would still need to use discretion: if too many links were submitted at once, "it pops up on the link graph” and could negatively affect search results (I5.4). - Scouting for new resources. Workers also sought external tools. As Daria said, "Sometimes the SEO team will find a new tool or process that will help us streamline things or just find new info so they'll talk about it and offer it. You just have to look for that stuff on your own and then present it to the team” (I2.1). Carl and Luis scouted such tools as well (O4.4, I4.4, O5.4, I5.4). As operationally autonomous agents, specialists ranged independently and brought valuable external resources back to their teams.

With these many types of customization, Semoptco had to provide a flexible organizational structure that would allow a high degree of operational autonomy but still enable constant communication among workers, keep projects on track, and foster constant innovation. 
Flexibility through Network Structure: Maintaining Team Cohesion in Contingency-Laden Work

What was the nature of this flexible organizational structure? It was an overlapping set of at least six teams, teams that functioned as networks (Table 1).

These networks were held together in part through coordinative and self-regulative genres. Semoptco was not an entirely "flat" organization, but below the upper management layer, workers enjoyed considerable autonomy, organized in networks where they played multiple roles and established multiple relations.

Specialists served on all these teams simultaneously. Each team had a well-defined scope; most were small; all focused on specific objectives. Stan explained that Semoptco desired "a lot of small nimble teams tackling specific problems: they could be internal problems, they could be client-focused problems” (I1.2).

Most teams did not have strongly defined leadership roles. For instance, although account managers nominally managed project teams, that management consisted of conveying reminders about the timetable and vetting reports for the clients (I2.1; I4.1/5.1). Similarly, although I had initially thought that support teams constituted a nascent middle management layer, Daria and Carl indicated (I2.4; I5.3) that her leadership role was support, not close management. As Daria put it, "the goal, especially with the reorganization, was to have ... more oversight and awareness of what's going on with clients" (I2.4). This structure matches Castells" description of the "e-firm" as "based on a flat hierarchy, a teamwork system, and open, easy interaction between workers and managers" (2003, p. 91); they "give workers as much initiative as they can handle, under conditions defined and organized by management” (p. 233) conditions that include team composition, timelines, and templates. 


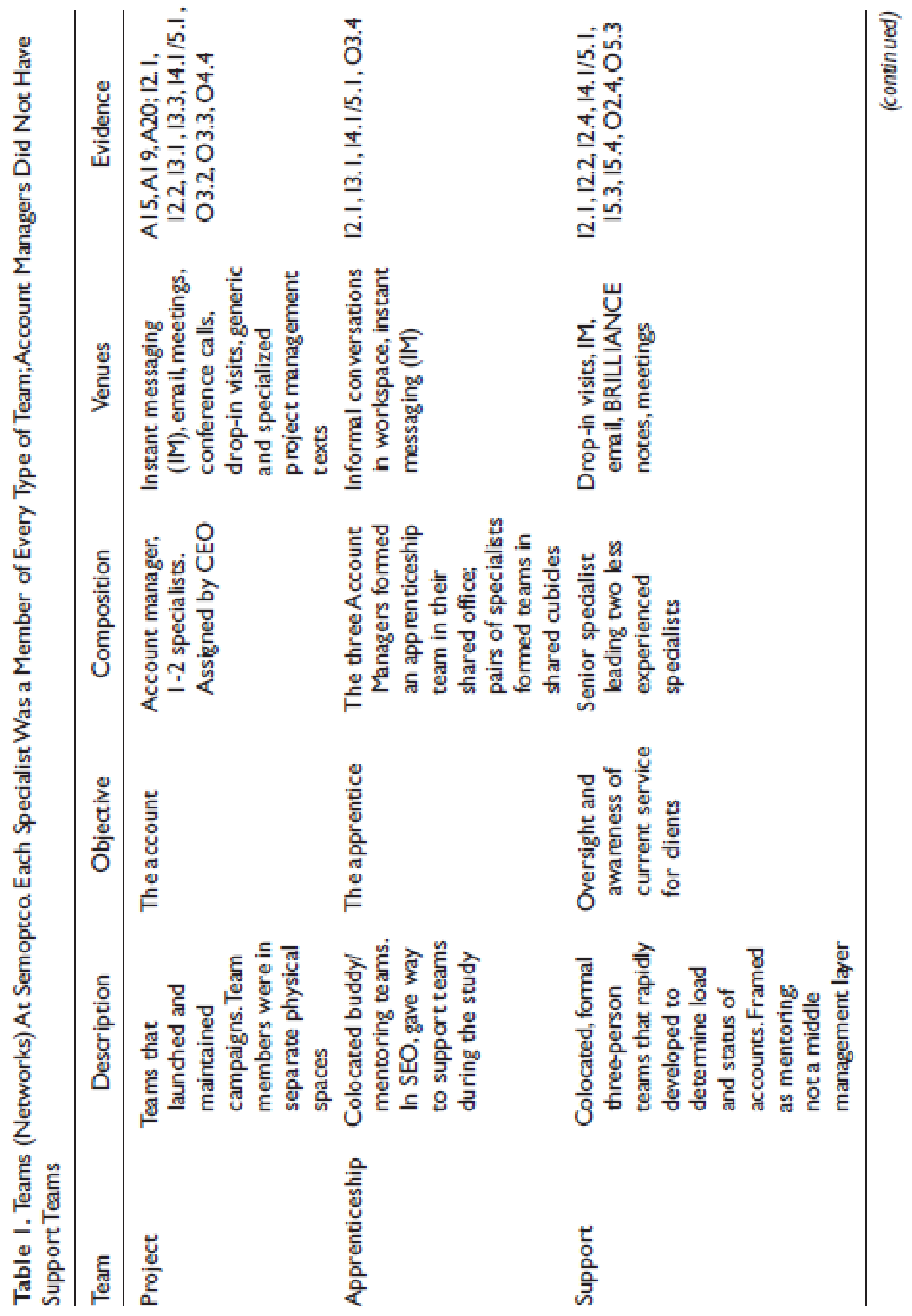




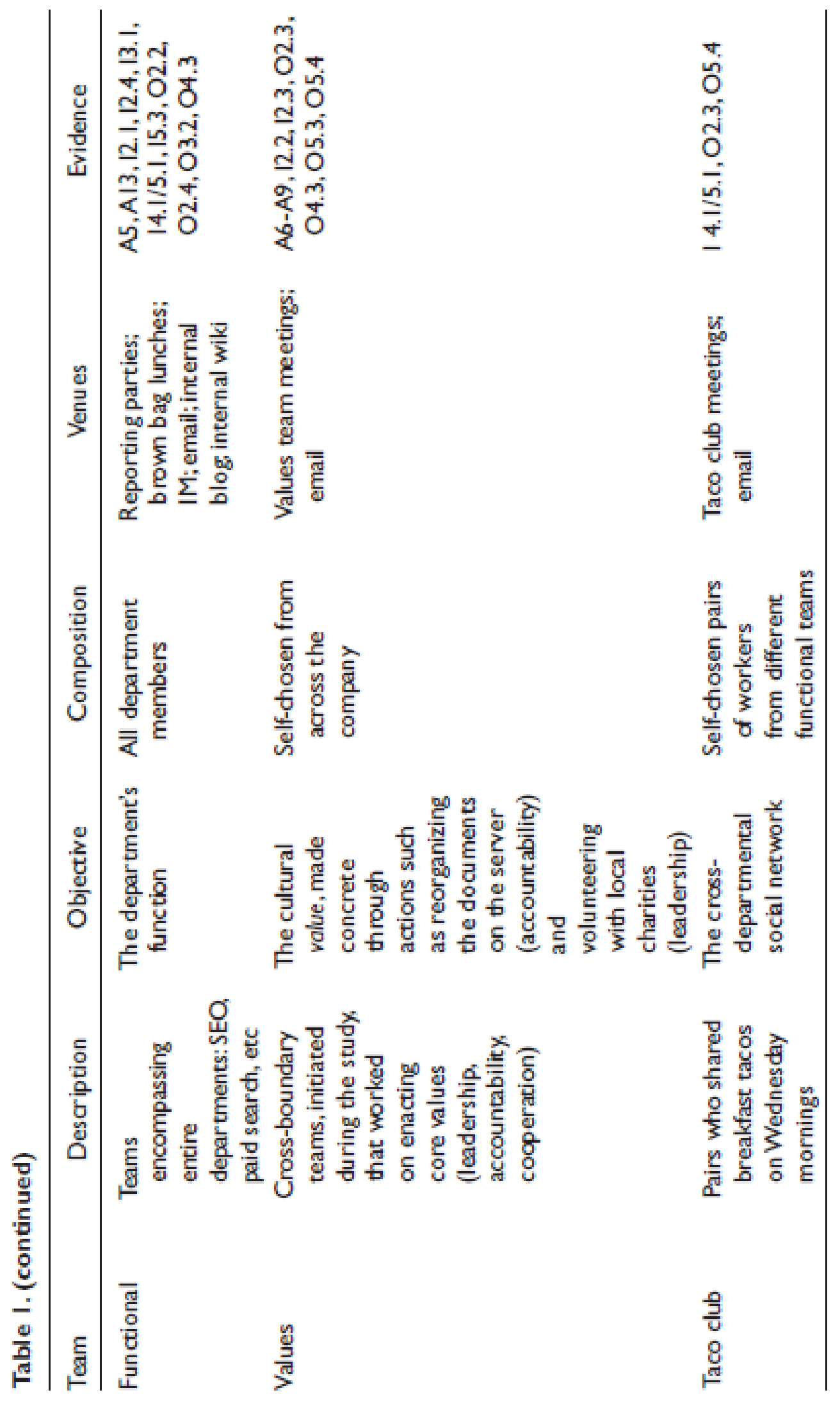


These teams, then, functioned as organizational networks: distributed, multiply linked, heterogeneous, objective-oriented but decentralized, and mutually overlapping. Each network had its own objective; each contributed to the problem solving that culminated in the monthly reports; in aggregation, the teams reached the objectives of Semoptco. Consequently, workers not only knew what relations they could draw upon when working on a specific project but they also established relationships across the entire company. One important tool for maintaining those relations was Semoptco's IM use. Every worker had an IM client running, listing every worker of the company who was logged in. Workers would log into IM as soon as they arrived, and they used IM to determine whether other workers had arrived (O4.4; I3.3). According to Stacy, IM had essentially replaced phone calls within Semoptco (I3.3).

In some cases, IM replaced even more familiar forms of contact. For instance, in one observation, Luis wanted to ask a question of Carl who shared his cubicle. He glanced at Carl, but Carl was listening to headphones. Rather than interrupting, Luis turned back to his screen and sent Carl an IM (O4.2).

This incident not only illustrates how important IM was at Semoptco but it also illustrates how autonomously specialists worked. I called this the "lone wolf model” in interviews with Daria and Carl (I2.1, I5.3), and they agreed, describing their work in memorable phrases such as "every man for himself" (Daria, I2.1) and "do whatever you need to do" (Carl, I5.3). Carl described specialists' isolation in this way: "For a new hire, just imagine, it's like you came in and you're on an island. And I don't necessarily dislike that” (I5.3). Similarly, Daria said that "there's no one saying 'do this, you have to do something like this'” (I2.1). Specialists developed their own routines, schedules, and time management procedures within the framework of monthly work cycles and launch milestones, diverged widely on how they spent their time and exercised considerable autonomy in selecting their tools, conducting individualized analyses, and customizing reports for clients. For instance, Daria, Luis, and Carl used a range of idiosyncratic checklists (O2.2, O2.4, O4.2, O4.4, O5.3, A17) and highlighting schemes (O4.2, O4.3). Not just anyone could take on this sort of role: Stan and Daria both specified that they looked for "self-starters" when hiring (I1.1, I2.1).

But these autonomous specialists also scouted new tools and information, continually moving the line between regulated and regularized genres. They developed genres for circulating their knowledge across apprenticeship, support, and functional teams, including shared documents (I2.1, O3.4), templates (I2.1, I3.1, I4.1/5.1, I4.3, I5.4, O3.4, O4.2, O5.4, A15, A16), copies of previous reports (O4.2, O4.3, O5.2), checklists in Google Docs (I2.3, O2.3, 
O2.4, O4.2), internal and external blogs (I4.1/5.1, I2.3, I5.3, O2.2, O2.3, O3.2), and meetings (I1.1, I4.1/5.1, I2.2, O2.2, O2.3, O2.4, O5.3, O4.3, O4.4, A5-A9). The scouting model had problems (I1.2), but it let Semoptco balance operational autonomy with the need to stabilize work. Ultimately, Semoptco's networks provided enough flexibility to conduct audience analysis and ethos moves well.

\section{Semoptco's Audience Analysis:Constant Boundary-Crossing} Audience analysis is the main product of SEO (Killoran, 2009), and monthly reports described progress in analyzing audiences. But it's the complicated sort of audience analysis done by marketing and advertising companies, the kind that simultaneously involves (a) analyzing the client, (b) analyzing the client's prospective customers, and (c) convincing the client that the customer analysis is correct. And it's even more complicated in that the specialists will probably never meet the client's customers, who may reside anywhere on the globe and who may not even know they are looking for the client's product, service, or information.

Semoptco had to address heterogeneous audiences:

- Clients. What customer behaviors should the client desire, based on the content, and how can Semoptco guide and educate them in selecting desired behaviors so that they can best connect client and customer?

- Intended Web site customers. Who is the intended customer audience for the Web site, and what behavior does the client desire from them?

- Current Web site customers. Who is the current customer audience for the Web site-people who are finding it already? What currently draws them? Which segments exhibit the behavior the client desires?

- Search engines. What practices are most likely to raise rankings for specific search engines and across search engines? Which will mostly likely result in flagging content?

Workers analyzed audiences in many ways, resulting partially in monthly reports: both explicitly (in goals) and implicitly (in selected keywords and recommendations such as developing specific kinds of site content to draw visitors). Let's see how they marshalled different texts, resources, and connections to coordinate audience analysis and then see how that audience 
analysis fed into the monthly report.

We can think of this audience analysis in terms of interessement (Callon, Lascoumes, \& Barthe, 2009) in which stakeholders are defined and put into relationship with one another. Part of what makes Semoptco's work so complicated is that this process is multidirectional: the four audiences interesse each other. For instance, the client may have unrealistic expectations about what customer behavior to desire, given the site content and the ability to encourage and monitor the behavior. The intended Web customers may not exhibit that behavior even if they come to the site. And the current Web customers may exhibit different behaviors, some of which could redefine what should be considered desirable. The search engines, finally, can be fickle in how they apply algorithms. Let's take one incident to illustrate.

The Challenges of Audience Analysis: Defining Stakeholders for a Medical Site During one observation (O2.2), Daria joined an account manager and two paid search specialists for a conference call with one of Semoptco's biggest clients. The client had several Web sites, including an informational Web site on medical issues. The client, which had been monitoring analytics for this site, wanted it to perform better. So after the conference call, the three specialists and the account manager discussed how to shape this site.

The account manager explained as follows: This is always a problem with this client's sites, how to monetize them. Currently, the only way to show value is through a feature to help patients find doctors. We keep throwing out ideas about showing results, she added, but none have stuck. One way to measure results, the one favored by the client, was through conversions. But as Daria pointed out, "Info stuff is just different." It was unclear whether this information really led people to seek a doctor. Daria asked whether the site should project authority and credibility instead. They discussed whether to conceive of the site in terms of branding. Then a paid search specialist asked as follows: Is anyone's dad a doctor? Can we get the inside scoop that way?

They discussed insurance companies as a possible audience. But, as Daria pointed out, "I just don't think this site is set up for conversions.” The mismatch between customer expectations and the site's content reminded them of another customer who was obsessed with bounce rate. All chuckled as they remembered this client, simultaneously viewing the site's analytics on their individual laptops. "I don't know what I'll do about this situation," the account manager sighed. Stymied, they brainstormed how to learn more about the audience that was already using the site. One asked as follows: Can we track who views videos to the end? Meanwhile, Daria copied down "pacemaker" and other popular keywords from the analytics into her notebook. 
In her postobservation interview, Daria explained,

This professional site ... has been really difficult. Because the other ones are all aimed at just consumers. So, you know, we can figure that stuff out really easily. But when you're talking about, okay, we want doctors to get here? Well, we're not doctors! We don't know, do the doctors search for this or do they search for the product name or do they search for the brand name or do they even search for it at all, do they look for it? So, yeah, and we don't know the process—so it's definitely been more difficult. (I2.2)

To gain insight, Daria reached out through her personal networks, just as the paid search specialist had suggested: "I've got friends in med school, and I've talked to them before." (I2.2)

Two weeks later, I observed Daria discussing this situation in a support team meeting with Carl, who had inherited this account. "People are searching for ICD even when they type in 'pacemaker,"” she told him. She suggested looking for professional resources for doctors: developing suitable keywords would be hard since they would have to figure out what doctors search for $(\mathrm{O} 2.4)$.

In this incident, three audiences collide. The client describes an intended Web site customer who leads to conversions-a customer who will contact doctors that the client represents. But that desired behavior isn't supported by this informational site, and anyway, how do you measure that behavior? Clients, who sometimes become obsessed with irrelevant analytics, are not necessarily the best judges; they must be guided to realistic goals for desired customer behavior. So the project team discusses what desired behaviorsand intended customers - the site could support. Branding is an obvious function for an informational site, but it's hard to measure or monetize directly. They return to the analytics: what current Web site customers are finding their way to the site, and how can we figure out what they're doing? Clues came from keyword analysis and from video analytics, but the project team also drew on personal connections and professional resources. And lurking behind all this was the fourth audience, the search engines, which wrote and rewrote the basic rules of access.

I saw similar incidents throughout my visits. But each incident had different contingencies, requiring customized border-crossing and specialized audience analysis techniques. 
The Techniques of Audience Analysis

So audience analysis was multidimensional and complex. Semoptco's SEO specialists saw clients as partners, but they also opportunistically saw personal acquaintances as possible partners (“Is anyone's dad a doctor?”). Semoptco’s workers deployed several audience analysis techniques, including the following:

Soliciting ideas from the client. Specialists solicited ideas from the client at launch, starting with the kickoff meeting, where they learned about the client's industry and solicited keyword suggestions (A13, A15, I4.1/5.1, I4.3, I5.3). "Usually they can give us at least some ideas," Daria explained. "Like 'In your industry do they call it this or this?' 'Well, they call it this.' 'Okay, good enough'” (I2.2). They also gathered client collateral, including offline sales and marketing materials, "so you know if they're pushing essentially a keyword offline, then obviously you want to optimize it online," Carl explained (I5.3). After generating a suggested keyword list, the specialists elicited more feedback from clients.

Generating ideas from competition. Specialists also generated ideas by examining competitors' sites and analytics during the competitor analysis (I4.1/5.1, I3.4, I4.4, O4.4, A14, A15, A18). Usually this meant examining the sites of competitors identified by the client, finding out what keywords drew customers for whom the client was competing, as well as keywords that competitors had missed. Occasionally, as Luis mentioned (I4.4), this also meant identifying more suitable competitors.

Generating ideas from analytics. Specialists also examined analytics for the client's site, both during the launch process and during maintenance (I1.1, I3.1, I2.2, I4.3, I5.4, O2.2, O2.3, O2.4, O4.2, O4.3, O5.2, O5.3, O5.4). Analytics provided better understanding of current customers as well as a sense of how well the site was drawing intended customers. But beyond that, analytics gave clues about productive variations that specialists might not have contemplated. For instance, in one observation (O5.4), Carl examined the analytics of a site that was intended for a U.K. audience. He discovered common misspellings of keywords as well as British spellings and terms (e.g., "medi" instead of "medical"). He used these to "try to optimize for the, the lingo. As much as possible" (I5.4).

Assessing clients' knowledge of Web development and analytics. Since SEO results depended in part on how well clients implemented Semoptco's recommendations, specialists assessed how well clients understood Web development, and they worked hard to find contacts with whom they could work. For instance, Luis recounted that one client's Web developer "understands everything” but the CEO "understands nothing” (O4.3). Carl said he 
liked to make contacts with clients' Web developers during the launch process to assess what they knew (I5.3). In another instance, Daria told an account manager over IM how relieved she was that their client's incompetent Web developer had been fired (O2.3). As Stacy explained, unlike paid search, SEO involves educating the customer (I3.1); specialists had to assess customers' current knowledge and ability to assimilate new knowledge.

Drawing on personal networks. As noted above, specialists looked past the strong ties in their organization, also drawing on weak ties (Granovetter, 1973) in their personal networks to understand sites that were not consumer-facing.

Multidimensional audience analysis isn't unique to SEO; but here, audiences were consciously being defined through traces such as misspelled keywords, traces that became incorporated into standing sets of transformations (e.g., by monitoring performance for these keywords). Specialists faced situations in which their potential audience could include nonhuman search engines and anyone who might use a search engine. To cut down the possibilities, they drew on personal networks and analytics to interesse relations among potential actors; once they had done so, they learned more about audiences through keyword analysis, guesswork, and personal networks. This interessement was never quite done, given changes in search engines, objectives, keyword performance, and even clients' Web sites. Consequently, Semoptco's specialists constantly engaged in border-crossing activities involving reciprocal changes to reports and the standing sets of transformations that produced them.

Audience analysis also helped Semoptco build its authority and trustworthiness: its ethos.

\section{Semoptco's Results: Constant Ethos-Building}

"Hey Jeannie," Stacy called to a more experienced account manager, "have you seen anything like this in a report?” (O3.4). She quoted from a draft monthly report stating that the customer's keyword results had dropped in response to the economy. "I have not seen anything like that," Jeannie responded. Together, they discovered that some keywords were related to lending, and on this morning of November 12, 2008, lending had been a big news topic due to the financial crisis. The client's rankings were unaffected relative to others in the same business, but news had taken up shelf space, crowding the client's results from the first few pages of search results.

"With a lot of news about those kinds of words, then they're just, like, taking up space in Google. So my client doesn't [have] as high rankings," Stacy explained later (I3.4). This was rather unusual. Semoptco had to 
explain it in the monthly report and outline a response. So Stacy edited the monthly report, changing one passage to "articles about the economy taking shelf space in Google," then making other changes.

This situation was unusual, but ethos-building was an everyday activity. In an industry characterized by "snake oil," Semoptco had to convince clients that it was not cheating them or being unscrupulous; that its results were measurable and verifiable; and that it had a higher degree of knowledge and experience of SEO than the clients themselves did. These arguments were sometimes significant challenges, challenges that were not only addressed in the monthly reports and meetings but also in framing texts such as emails that account managers and specialists sometimes sent to clients.

Although Semoptco certainly worked on building its ethos for other audiences, particularly search engines, let's examine ethos work aimed at paying clients.

The Challenges of Ethos: Threats to Semoptco's Reputation. In this contingency-laden sector, building ethos was not easy. Beyond "snake oil," Semoptco had to anticipate and coherently explain the contingencies that perturbed its results, and it also had to manage clients' own (potentially damaging) actions.

The threat of contingencies. Although contingencies such as algorithm changes and news topics might change rankings unpredictably, Semoptco had to demonstrate that their work generally helped clients to raise their rankings sustainably and predictably over the medium to long term.

The threat of clients. Of course, confidence was a two-way street. Clients themselves represented a contingency: after all, they owned and controlled the Web sites that Semoptco was trying to optimize. Ehen Semoptco took on a client; part of the launch process involved evaluating the client's current Web site (I4.1/5.1, A14, A18). Had the Web site been well constructed? Or had well-meaning Web masters or previous SEO firms built the site in ways that raised red flags for search engines? (I4.1/5.1). Did clients think they knew more than they actually did, and would they fight Semoptco's recommendations, question Semoptco's choice of analytics, and make changes without informing Semoptco? Semoptco met those threats with specific ethos techniques.

The Techniques of Ethos: Framing Results Semoptco applied several techniques that involved anchored, stable reporting as well as flexibly enacted updating and customization. 
"Report cards". As Stan mentioned in the site interview, Semoptco generated "report cards": measurable, verifiable, reliable summaries of how their SEO was performing relative to targets set during the launch process. These "report cards" appeared in monthly reports under the heading "Analysis of Natural Search Campaign Performance” and contained tables describing campaign rankings, rankings summary, traffic, conversion rate, and visitors (A19, A20). At the time of data collection, Semoptco was considering making the "report cards" available online via BRILLIANCE (I4.1/5.1). These data-driven results allowed Semoptco to show precisely where keywords were performing well, where they were not, and what trends they were following. But they also allowed clients and SEO specialists alike to see what progress they had made on their stated goals. In the first- and second-tier reports, specialists also spelled out this progress with analytical sections. As Semoptco's collateral warned, results could take months to show (A13; cf. O4.3); the monthly "report cards" helped both parties to detect these results.

Standard monthly reports. The "report cards" were part of the monthly reports, which also included methods, action items, and short- and long-term strategies (A19, A20). These reports allowed Semoptco to surface its methods in the Analysis sections and to establish long-term framing in the Goals and Objectives, reminding customers that SEO takes time. Like "report cards," reports were increasingly automated through BRILLIANCE, templated in Microsoft Word, and then vetted by SEO specialists and account managers. Reports included an executive summary, campaign overview, action items, goals and objectives, analysis, budget status, and campaign history.

Customized analysis. As discussed earlier, Luis and Daria both produced supplemental, customized analyses in specific situations, incorporated into reports and corresponding client meetings $(\mathrm{O} 4.4, \mathrm{O} 2.2)$. Both indicated in interviews that such customized analyses were not usual, but they were not rare either, mostly applied to Tier 1 clients with special situations (I4.4, I2.2). As Castells notes, layering customization on top of an automated productsuch as a customized analysis attached to a templated, largely autogenerated report - is "the key to the new form of conducting business" (2003, p. 77; cf. Engeström, 2008). Semoptco had developed a balance between automating BRILLIANCE reports and adding customized analysis, that is, between loosely regularized innovations and regulated solutions.

Relationships. Beyond these documents, specialists maintained relationships with clients, both through formal meetings and through less formal ongoing contact. They individually maintained these relationships, generally at the specialist's discretion.

For instance, Luis and Carl stressed how important it was to assess the 
client and the client's Web site. Sometimes "clients will make changes without telling us" or perhaps the client's site is "hiding some stuff” because "they are building it for robots, not for the users," Luis argued. Or perhaps the site uses "cloaking" (showing different content to humans and to search engines), Carl added (I4.1/5.1; cf. O5.3). Other factors included frames, flash, titles, and ALT text for figures. But these technical issues signaled relational ones. Would the client change the site without telling Semoptco? How had the client previously constructed the site? Did the client's site actually hurt them at present, creating a hole from which Semoptco had to dig them out?

Consequently, specialists sought to form ongoing collaborative relationships with clients. After one meeting, Carl explained, "Social media is a big part of what we do ... [it is] very much about the user, you need to get out there and interact with them. So anytime a client is willing and able to do that, it's like [claps] yes!” (I5.3). During that day's observation, Carl read a Wired article that related to a client, so he emailed the client representatives the article's Web address and a short explanation (O5.3, I5.3). Such contacts were highly individualized. These contacts were important in part because they allowed specialists to negotiate the level of trust with the client. Luis, for instance, discussed how he sometimes approached clients when he wanted to test new techniques on their Web site (I4.3). Clients were naturally worried that an untested technique might hurt their brand, so Luis deployed ethos arguments to overcome these fears.

As the specialists developed their individual relationships with clients, they were able to build trust in this uncertain environment, and that trust helped them to implement farther-ranging reforms, generating better measurable results. Trust, negotiated between the monthly reports, led to changes in direction that were then instantiated in subsequent reports' goals, methods, and keyword analyses.

In sum, Semoptco's approach to ethos-building involved (a) generating a stable set of reporting measures through automation and (b) customizing that base product through innovations, specifically actions that individual specialists took largely of their own volition. Together, these two moves generated ethos - an ongoing accomplishment of trust optimized for their network. Yet this combination yields divergent practices, so Semoptco periodically overhauled its automated systems and templates (I2.4, I5.4), constantly turning regularized innovations into regulated genres, thus cyclically stabilizing its practices. 


\section{Implications}

How did specialists at Semoptco manage to produce large numbers of structurally and rhetorically complex reports, month after month, while dealing with constant changes? As we've seen, the monthly report is only a small part of the writing and reading they did as they completed monthly launch and maintenance cycles.

To write these reports, they deployed a large assemblage of genres as a relatively stable set of standing transformations. It's easy to fixate on the most obvious text (the report) and the most obvious feature of its construction (the fact that it was largely automated, the result of pouring database entries into a template). But behind this automated construction stood many other transformations, effected by texts of varying formality, maturity, and discretion. These texts were related to social practices: practices as minor as eating breakfast tacos together, as subtle as checking on someone's availability by seeing if they are logged into IM, and as offbeat as awarding a decorated mannequin head as a teamwork trophy (A5). Such practices helped to connect overlapping teams so they had plenty of resources on which to draw as they addressed contingencies and circulated solutions.

Semoptco's teams needed this flexibility because SEO is such a highly contingent industry. Part of the flexibility involved the freedom to develop textual innovations, to seek out alternate ways to enact standing transformations, to establish expanded and unsupervised relationships with clients, and to reach out through personal contacts to analyze audiences. Increasingly, those audiences included nonhuman agents such as search engines, unpredictable human agents such as people who misspell keywords, and unfamiliar agents such as specific customers looking for specialized information.

At the same time, innovated responses to new situations became part of reports and other documents, forming a repository that others could draw upon. Once an innovation was included in a report, it became a candidate for reuse, turning from a loosely regularized innovation into a regulated genre. Similarly, once a process was automated, it became available to a much broader set of specialists.

Whether a solution was encapsulated as a genre (or genre feature) in a report or automated in a tool (such as a link building tool, a social bookmarking tool, or an analytics tool), it became regulated-the problem solving had been worked out - and that meant that specialists could turn to high-autonomy, high-discretion analytical work, developing additional analytical innovations. As Castells argues, they could work on customizing services for a given customer. And this was the real "secret sauce" of Semoptco: not simply that they could provide data-driven analyses but that they could use these analyses 
as bases for flexibly customized analyses. Rather than leading to a discohesive genre assemblage, this process led workers to autonomously develop analyses and innovations, communicate them, and integrate them into more regulated structures so that they could be examined, developed, and reused.

And here we see a chance for developing WAGR for knowledge work. In WAGR, as we've seen, genres are expected to form, accrete, and develop in response to extended recurrent situations: for instance, describing experimental results over centuries (Bazerman, 1988), transforming accounting figures according to slowly developing disciplinary rules (Devitt, 1991), or analyzing traffic data over decades (Spinuzzi, 2003, Ch.3). But at Semoptco, specialists rapidly developed genres and practices-not on the scale of decades or centuries, but over weeks - and many of these genres and practices quickly became automated or templated. Traditional WAGR simply hasn't been geared for examining such rapid change or its conditions, but the pace and conditions are becoming more common in sectors that focus primarily on analyzing and transforming textual information. This study suggests that WAGR can be applied to such environments as well, environments that are characterized by border crossing, continual learning, and contingency.

At this point, WAGR needs more, and more rigorous, studies on such rapidly changing, automated genres and how those genres contribute to arguments. What does it mean for rhetorical genre theory that so many genres are becoming automated and customized for specific problems? More specifically, if knowledge workers focus on innovative, customized aspects of work rather than the recurrent situations toward which genres are oriented, does the role of genre shift in knowledge work? This study suggests that it does, but confirmatory studies are needed. 


\section{Appendix A.}

Codes

Starter Codes

\begin{tabular}{|c|c|c|}
\hline Code & Description & Example \\
\hline $\begin{array}{l}\text { TIME \& PROJECT } \\
\text { MANAGEMENT }\end{array}$ & $\begin{array}{l}\text { Keeping projects on } \\
\text { track.Allocating } \\
\text { time and labor, } \\
\text { coordinating and } \\
\text { delegating work, } \\
\text { and holding clients } \\
\text { accountable for } \\
\text { agreements on } \\
\text { how projects are } \\
\text { scheduled and } \\
\text { executed }\end{array}$ & $\begin{array}{l}\text { >Chrome: BRILLIANCE:Task. "Look Into correlation } \\
\text { between elther positive or negative effect of testing/ } \\
\text { Implementation on SEO." (O5.4) }\end{array}$ \\
\hline UNDERSTANDING & $\begin{array}{l}\text { Learning about others' } \\
\text { work, business. } \\
\text { Discovering and } \\
\text { applying knowledge } \\
\text { about clients' and } \\
\text { subcontractors' } \\
\text { disciplinary languages, } \\
\text { flelds, activitles, and } \\
\text { work styles }\end{array}$ & $\begin{array}{l}\text { Outlook emall. "Hey [pald search speclalist]. l'm a little } \\
\text { confused about the second part of your emall ...." } \\
\text { (O3.3) }\end{array}$ \\
\hline TRUST & $\begin{array}{l}\text { Expressing, extending, } \\
\text { bullding, or losing } \\
\text { trust in someone. } \\
\text { Assurance that a } \\
\text { collaborator or client } \\
\text { will consistently } \\
\text { behave in a way } \\
\text { positive to the } \\
\text { ongoing relationship }\end{array}$ & $\begin{array}{l}\text { At 3, client meeting with [Client] (he worked this last } \\
\text { time). Their Web dev [name redacted] understands } \\
\text { everything. Owner [name redacted] understands } \\
\text { nothing. They use [Web developer] as translator. Both } \\
\text { are coming today. (O4.3) }\end{array}$ \\
\hline STRATEGY & $\begin{array}{l}\text { Strategic plans and } \\
\text { moves: Selecting } \\
\text { projects, pursuing } \\
\text { clients, selecting } \\
\text { collaborators with } \\
\text { a long-term agenda } \\
\text { in mind. Particularly } \\
\text { includes growing and } \\
\text { positioning business }\end{array}$ & $\begin{array}{l}\text { DARIA:... the way the organization operates now vs. } \\
\text { when It was a I0-person company Is very different, } \\
\text { natural search is very different, [it was a] much less } \\
\text { strategic fleld, It was-there was much less thought to } \\
\text { It. there was more "okay, I'm just going to bulld some } \\
\text { IInks that look like this and It'll be good." And to some } \\
\text { extent you can stlll do that. but Google doesn't want } \\
\text { to do that, and Google flgures that out and starts } \\
\text { evolving and you have to evolve with It.... (I2.I) }\end{array}$ \\
\hline TRAINING & $\begin{array}{l}\text { Training for this } \\
\text { particular job. } \\
\text { Recelving and } \\
\text { providing knowledge } \\
\text { and procedures } \\
\text { needed to perform } \\
\text { work approprlately }\end{array}$ & $\begin{array}{l}\text { STACY:Well, It can be two to three [people in a project } \\
\text { team].And when a new account manager Joins, It's } \\
\text { usually an account manager that's been here before, } \\
\text { and then the new account manager will kind of work } \\
\text { with that person to kind of learn the ropes. So It's } \\
\text { usually pretty small teams, though. (I3.I)| }\end{array}$ \\
\hline
\end{tabular}




\title{
Appendix A. (continued)
}

\author{
Open Codes
}

\begin{tabular}{ll}
\hline Code & \multicolumn{1}{c}{ Description } \\
\hline ACCOUNTABILITY & $\begin{array}{l}\text { Measures to ensure that } \\
\text { collaborators and clients } \\
\text { lived up to their implicit or } \\
\text { explicit agreements }\end{array}$
\end{tabular}

AUDIENCE

AUTONOMY

CLIENTS

CYCLES
Expressions of concern about how end users would select keywords or understand content

Working with operational autonomy, such as choosing particular tasks and how to execute them. Includes subcategories: isolation, lone wolf, and mobility

Discussion of or communication with clients. Subcategories included client compliance with recommendations, client infighting, and client tiers based on types of service contracts

Indicators of Semoptco's work cycles. Subcategories included recurrent cycles (daily, weekly, monthly, yearly) and project stages (launch, maintenance)
STACY:Yeah, I mean we definitely try to get things out. But we usually set expectations that it's an end-of-day deliverable. So it's not-you know, we try to get things done early when we can. (I2.I) $>$ cws. Info stuff is just different. Don't know that it converts in terms of sending them to Dr. Establish authority, credibility instead. (O2.2)

CARL: It probably would be different 'cause you have, that first third of the month is reporting, the middle third is meetings with the clients about those reports ... that last third is even more "do whatever you need to do." (I5.3)

Document. "Natural Search

Progress Report Prepared for. .."A sanitized report for a Tier I client. I8pp. (AI9)

CARL: It probably would be different 'cause you have, that first third of the month is reporting, the middle third is meetings with the clients about those reports ... that last third is even more "do whatever you need to do." (15.3) 


\section{Appendix A. (continued)}

\begin{tabular}{|c|c|c|}
\hline Code & Description & Example \\
\hline FLUX & $\begin{array}{l}\text { Examples or discussions of } \mathrm{L} \\
\text { organizational, automation, } \\
\text { and market changes }\end{array}$ & $\begin{array}{l}\text { Luis is in new cubicle, paired } \\
\text { with [another senior specialist] } \\
\text { now. I ask: b/c you are Carl } \\
\text { were working too closely? } \\
\text { (from Carl interview I0-I5). } \\
\text { No, they just move him } \\
\text { around. She's manager; he's not } \\
\text { mentoring her. (O4.4) }\end{array}$ \\
\hline HIRING & $\begin{array}{l}\text { Discussions of hiring policy } \\
\text { or strategy }\end{array}$ & $\begin{array}{l}\text { DARIA: I mean, it's kind of- } \\
\text { there's very little-oversight. } \\
\text { There's not a lot of oversight. } \\
\text { The account manager provides } \\
\text { some of that. If you don't get } \\
\text { stuff done for the client they're } \\
\text { gonna say, excuse me, what } \\
\text { are you doing? ....And we have } \\
\text { to hire carefully to make sure } \\
\text { we get people who are sort } \\
\text { of-(I2.I) }\end{array}$ \\
\hline KEYWORDS & $\begin{array}{l}\text { Discussions or examples of } \mathrm{F} \\
\text { keywords; subcategories } \\
\text { included selection, } \\
\text { measurement, and } \\
\text { deployment }\end{array}$ & $\begin{array}{l}\text { FF: analytics. Traffic sources -> } \\
\text { keywords -> nonpaid visits. } \\
\text { Search in page for "relief } \\
\text { valves" (O4.2) }\end{array}$ \\
\hline MEETINGS & $\begin{array}{l}\text { Discussions or examples of } \mathrm{L} \\
\text { meetings in which workers } \\
\text { assembled in person, either } \\
\text { informally in hallways or } \\
\text { formally in brown bag } \\
\text { meetings and reporting } \\
\text { parties }\end{array}$ & $\begin{array}{l}\text { L. says: had co. mtg yesterday. } \\
\text { Stated core values. Created } \\
\text { teams to focus on three core } \\
\text { values. Each will expand values. } \\
\text { Ex: Fri, go to food bank. (O4.3) }\end{array}$ \\
\hline REACTIVE & $\begin{array}{l}\text { Discussions or examples of } \\
\text { organizing work around } \\
\text { triggers, both cyclical } \\
\text { incidents and contingencies, } \\
\text { rather than planning work } \\
\text { tasks in advance }\end{array}$ & $\begin{array}{l}\text { CARL: So that shift to data-only } \\
\text { [reports] has been great for } \\
\text { increasing the amount of time } \\
\text { we have to prep and to actually } \\
\text { let it sink in and think. Like, just } \\
\text { reacting, you don't necessarily } \\
\text { have that opportunity to just } \\
\text { be awash in it .... (I5.3) }\end{array}$ \\
\hline
\end{tabular}




\section{Appendix A. (continued)}

\begin{tabular}{|c|c|c|}
\hline Code & Description & Example \\
\hline SCOUTING & $\begin{array}{l}\text { Discussions or incidents } \\
\text { involving individuals } \\
\text { discovering potentially } \\
\text { useful tools, services, or } \\
\text { procedures, and then } \\
\text { sharing them with others } \\
\text { on their teams }\end{array}$ & $\begin{array}{l}<\text { cw. Interns will love this. } \\
\text { [A social bookmark submitter] } \\
\text { (they do most of social } \\
\text { bookmark submitting) (O5.4) }\end{array}$ \\
\hline SEARCH & $\begin{array}{l}\text { Discussions or incidents } \\
\text { involving enacting, } \\
\text { explaining, or understanding } \\
\text { components of the search } \\
\text { business }\end{array}$ & $\begin{array}{l}\text { Document. "Natural search } \\
\text { services for <client>." List } \\
\text { of services and deliverables } \\
\text { by date, with deliverables } \\
\text { from Apogee and client } \\
\text { differentiated. (AI5) }\end{array}$ \\
\hline SNAKE OIL & $\begin{array}{l}\text { Discussions or incidents } \\
\text { involving deceptive SEO } \\
\text { practices, including "gray" } \\
\text { practices, false positives, } \\
\text { and search engine } \\
\text { detection of SEO gaming }\end{array}$ & $\begin{array}{l}\text { Cws. They discuss. Client } \\
\text { can't do paid blogging, etc.- } \\
\text { legal-can't pay people to say } \\
\text { anything re quality of surgery. } \\
\text { If we have interns do blog } \\
\text { comments, have to check work } \\
\text { off before post. (O2.4) }\end{array}$ \\
\hline STABILITY & $\begin{array}{l}\text { Measures for enacting } \\
\text { stability, including } \\
\text { subcategories: automation, } \\
\text { reuse }\end{array}$ & $\begin{array}{l}\text { DARIA:Yeah, they're all in our } \\
\text { server, so we can look at } \\
\text { anything anyone else has done, } \\
\text { pretty much. And it's definitely } \\
\text { helpful to see the way the } \\
\text { different templates are, and } \\
\text { the templates try to be more } \\
\text { standardized, but sometimes } \\
\text { older ones will sneak in. So } \\
\text { if there's a really good one I } \\
\text { know about, then I can say, } \\
\text { here's a really good one, use } \\
\text { this, and I can throw that one } \\
\text { in for the specialist to look at. } \\
\text { (I2.I) }\end{array}$ \\
\hline STATUS & $\begin{array}{l}\text { Discussions or incidents } \\
\text { in which team members } \\
\text { communicate or request } \\
\text { status on a project or client }\end{array}$ & $\begin{array}{l}<\mathrm{IM}([\text { account manager] }) . \\
\text { continue talking re status and } \\
\text { mtg needs }(\mathrm{O} 2.2)\end{array}$ \\
\hline
\end{tabular}




\section{Appendix A. (continued)}

\begin{tabular}{|c|c|c|}
\hline Code & Description & Example \\
\hline TALK & $\begin{array}{l}\text { Incidents in which team } \\
\text { members communicated } \\
\text { orally rather than via texts } \\
\text { (such as instant messaging, } \\
\text { email, reports) or tools } \\
\text { (phone) }\end{array}$ & $\begin{array}{l}<\text { cw. Remembers another } \\
\text { customer who was obsessed } \\
\text { with bounce rate. All chuckle. } \\
\text { (O2.2) }\end{array}$ \\
\hline TEAMS & $\begin{array}{l}\text { Discussions or incidents } \\
\text { involving teamwork. } \\
\text { Subcategories include types } \\
\text { of teams; team roles; team } \\
\text { behaviors; experience; and } \\
\text { scaling }\end{array}$ & $\begin{array}{l}\text { Photo. Poster for core value I: } \\
\text { Cooperation. P4 selected this } \\
\text { s one. (A7) }\end{array}$ \\
\hline TOOLS & $\begin{array}{l}\text { Discussions or incidents } \\
\text { involving tools, broadly } \\
\text { speaking, including texts, } \\
\text { images, and software }\end{array}$ & $\begin{array}{l}\text { Rolls R, looks in folder. Info on } \\
\text { this client. Progress reports. } \\
\text { Looks at old reports, all } \\
\text { marked up like the current one. } \\
\text { Finds one, brings to ctr. (O4.2) }\end{array}$ \\
\hline UNIQUE & $\begin{array}{l}\text { Discussions or incidents } \\
\text { involving contingencies } \\
\text { that participants indicated } \\
\text { were unique, resulting in } \\
\text { customized analysis or } \\
\text { reporting }\end{array}$ & $\begin{array}{l}\text { STACY:Yeah, we have a lot of } \\
\text { email templates.And some } \\
\text { of them are more formally } \\
\text { worded than necessary, but it's } \\
\text { a good thing to take and say, } \\
\text { okay, let's change this part. So } \\
\text { we work off a lot of templates, } \\
\text { but there's a lot of adjusting to } \\
\text { a specific project. (I3.I) }\end{array}$ \\
\hline WRITING & $\begin{array}{l}\text { Discussions or incidents } \\
\text { involving writing, including } \\
\text { the forms of writing listed } \\
\text { under TOOLS }\end{array}$ & $\begin{array}{l}\text { STACY:Yeah, um, I mean, each } \\
\text { specialist who sends a report, } \\
\text { they're always different, so they } \\
\text { each need a different amount } \\
\text { of editing. So after looking at } \\
\text { them the past few months and } \\
\text { kind of learning, you know, } \\
\text { sometimes things just look } \\
\text { wrong. So I was just asking her } \\
\text { if she had seen anything like } \\
\text { that. Usually when SEOs see } \\
\text { kind of a trend, then they'll all } \\
\text { insert kind of the same type of } \\
\text { language.... (I3.4) }\end{array}$ \\
\hline
\end{tabular}




\section{Appendix A. (continued)}

\begin{tabular}{|c|c|c|}
\hline \multicolumn{3}{|l|}{ Axial Codes } \\
\hline Code & Description & Example \\
\hline AUDIENCE ANALYSIS & $\begin{array}{l}\text { Discussions of, or } \\
\text { incidents involving, } \\
\text { building a structured } \\
\text { picture of how end } \\
\text { users search for } \\
\text { content or what } \\
\text { end users the clients } \\
\text { want to attract. Based } \\
\text { on codes: audience, } \\
\text { understanding, } \\
\text { search_keywords, } \\
\text { search_analytics, } \\
\text { search_local }\end{array}$ & $\begin{array}{l}\text { cws. Info stuff is just different. } \\
\text { Don't know that it converts in } \\
\text { terms of sending them to Dr. } \\
\text { Establish authority, credibility } \\
\text { instead. (O2.2) }\end{array}$ \\
\hline ETHOS & $\begin{array}{l}\text { Discussions of, or } \\
\text { incidents involving, } \\
\text { building authority } \\
\text { and trust. Based } \\
\text { on codes: snakeoil, } \\
\text { accountability, trust, } \\
\text { clients_compliance }\end{array}$ & $\begin{array}{l}\text { >Word: (continues). “Our Web } \\
\text { master contact 'gets it,' but } \\
\text { we need to make sure [client } \\
\text { CEO] and the others do as } \\
\text { well. Need to clean up HTML, } \\
\text { JS, Flash when redesigned site } \\
\text { is up." More text like this, with } \\
\text { numbers corresponding to } \\
\text { clients in the numbered list } \\
\text { above. (O5.3) }\end{array}$ \\
\hline FLEXIBILITY & $\begin{array}{l}\text { Discussions of, or } \\
\text { incidents involving, } \\
\text { making work and } \\
\text { work organization } \\
\text { flexible in order to } \\
\text { rapidly react to flux. } \\
\text { Based on codes: flux, } \\
\text { stability_automation, } \\
\text { scouting, autonomy, } \\
\text { reactive, clients_ } \\
\text { infighting, hiring }\end{array}$ & $\begin{array}{l}\text { CARL:Yeah. That was another } \\
\text { reason for the change, is } \\
\text { that this provides a lot more } \\
\text { structure. So when you do } \\
\text { come in, it's a lot easier to tell. } \\
\text { And not even-for a new hire, } \\
\text { just imagine, it's like you came } \\
\text { in and you're on an island.And I } \\
\text { don't necessarily dislike that.... I } \\
\text { do like a bureaucracy of [makes } \\
\text { whistling noise] of these blocks } \\
\text { up above. But it will make it } \\
\text { easier to, I think, help you out } \\
\text { with where you can be and } \\
\text { where you can improve. (I5.3) }\end{array}$ \\
\hline
\end{tabular}




\section{Appendix A. (continued)}

\begin{tabular}{|c|c|c|}
\hline Code & Description & Example \\
\hline NETWORKS & $\begin{array}{l}\text { Discussions of, or } \\
\text { incidents involving, } \\
\text { recombinant } \\
\text { networks of team } \\
\text { members organized } \\
\text { around a project. } \\
\text { Based on codes: } \\
\text { teams, tools_im, } \\
\text { meetings }\end{array}$ & $\begin{array}{l}\text { STACY: Right. Especially in } \\
\text { the launch process, there's a } \\
\text { lot more, you know, specific } \\
\text { deliverables. you're checking } \\
\text { on, or questions ... then once } \\
\text { a client gets in maintenance } \\
\text { mode, it's less contact and } \\
\text { more-every few weeks, } \\
\text { try to touch base on things. } \\
\text { (I3.I) }\end{array}$ \\
\hline TRANSFORMATIONS & $\begin{array}{l}\text { Discussions of, or } \\
\text { incidents involving, } \\
\text { enacting, and using } \\
\text { standing sets of } \\
\text { transformations. } \\
\text { Based on codes: } \\
\text { stability_reuse, } \\
\text { stability_automation, } \\
\text { tools_templates }\end{array}$ & $\begin{array}{l}\text { STACY:Yeah, we have a lot of } \\
\text { email templates. And some } \\
\text { of them are more formally } \\
\text { worded than necessary, but } \\
\text { it's a good thing to take and } \\
\text { say, okay, let's change this } \\
\text { part. So we work off a lot of } \\
\text { templates, but there's a lot } \\
\text { of adjusting to a specific } \\
\text { project. (I3.I) }\end{array}$ \\
\hline
\end{tabular}

\section{Appendix B}

\section{Questions for Semistructured Site Interview}

- How do people in your organization manage projects? What tools and texts do they use?

- What current problems do you see with project management in your organization? What are your plans for addressing them?

- How, and to what extent, do your team members collaborate in management? For instance, to what degree do they shape objectives, set milestones, and determine processes and delegation?

- How, and to what extent, do your team members share information?

- What project management training have they received?

- How has project management changed in your organization over the last few years? How do you expect it to change in the near term? 


\section{Appendix C.}

Questions for Semistructured Preobservation Interview

- What is your job history? Could you tell me about the sorts of jobs you have held beyond this one?

- What is your academic background? Could you tell me a bit about your educational experience?

- How would you describe your current job? What are your most important duties or activities?

- What team or teams do you work in? Can you describe your current project?

- How does this team manage this project (e.g., objectives, milestones, delegation)? What tools and texts do they use?

- How does your team share information? To what extent?

- What training have you received in teamwork and project management?

- How has project management changed in your organization?

\section{Appendix D.}

- Questions for Semistructured Postobservation Interview

- I noticed that some of your activities included (list from observation). How did you learn how to deal with these project-related duties and activities?

- Would you say that this was a typical day? Tell me about where you are in this project.

- I noticed that you (observation about how they communicate within their temporary networks). Could you tell me a bit about the ways that you communicate with clients, vendors, subcontractors, and others?

- These projects tend to be pretty complex, with a lot of things to coordinate. I noticed that you (observation about time and project management). Could you talk a bit about how you manage your time and projects?

- I also noticed that you (observation about working with others). To make these projects successful, do you need to know much about the work of clients, vendors, subcontractors, and others? If so, how do you learn about their work?

- Do you tend to work frequently with the same vendors or subcontractors? How do you maintain those relationships?

- Where do you see your business or unit five years from now? What are your goals? Do you see projects like this one contributing to those long-term goals? 


\begin{tabular}{|c|c|c|c|}
\hline \multicolumn{4}{|l|}{ Interviews } \\
\hline Interview number & Date & Participant & Type of interview \\
\hline II.I & $9 / 4 / 08$ & Stan & Site \\
\hline 12.1 & $9 / 24 / 08$ & Daria & Preobservational \\
\hline 13.1 & $9 / 24 / 08$ & Stacy & Preobservational \\
\hline $14.1 / 5.1$ & $9 / 24 / 08$ & Luis and Carl & Preobservational \\
\hline 14.3 & $10 / 15 / 08$ & Luis & Postobservational \\
\hline 15.3 & $10 / 15 / 08$ & Carl & Postobservational \\
\hline 14.4 & $10 / 22 / 08$ & Luis & Postobservational \\
\hline 15.4 & $10 / 22 / 08$ & Carl & Postobservational \\
\hline 12.2 & $10 / 29 / 08$ & Daria & Postobservational \\
\hline 13.3 & $1 \mathrm{I} / 5 / 08$ & Stacy & Postobservational \\
\hline 12.3 & $1 \mathrm{l} / 5 / 08$ & Daria & Postobservational \\
\hline 12.4 & $1 \mathrm{I} / 12 / 08$ & Daria & Postobservational \\
\hline 13.4 & $1 \mathrm{I} / 12 / 08$ & Stacy & Postobservational \\
\hline 11.2 & $8 / 6 / 2009$ & Stan & Site \\
\hline
\end{tabular}

Observations

\begin{tabular}{lll}
\hline Observation number & Date & Participant \\
\hline O4.2 & $10 / 8 / 08$ & Luis \\
O5.2 & $10 / 8 / 08$ & Carl \\
O4.3 & $10 / 15 / 08$ & Luis \\
O5.3 & $10 / 15 / 08$ & Carl \\
O4.4 & $10 / 22 / 08$ & Luis \\
O5.4 & $10 / 22 / 08$ & Carl \\
O2.2 & $10 / 29 / 08$ & Daria \\
O3.2 & $10 / 29 / 08$ & Stacy \\
O2.3 & $11 / 5 / 08$ & Daria \\
O3.3 & $11 / 5 / 08$ & Stacy \\
O2.4 & $11 / 12 / 08$ & Daria \\
O3.4 & $11 / 12 / 08$ & Stacy \\
\hline
\end{tabular}




\section{Appendix E. (continued)}

Artifacts

\begin{tabular}{|c|c|c|c|}
\hline Artifact number & Participant & Date collected & Artifact description \\
\hline $\mathrm{Al}$ & Luis & 2008-10-08 & $\begin{array}{l}\text { Photo. Sticky notes on cabinets, } \\
\text { right side }\end{array}$ \\
\hline $\mathrm{A} 2$ & Carl & $2008-10-08$ & $\begin{array}{l}\text { Photo. Sticky notes on cabinet, } \\
\text { left side }\end{array}$ \\
\hline A3 & Carl & $2008-10-08$ & $\begin{array}{l}\text { Photo. Workspace, including } \\
\text { printouts, sticky notes (left } \\
\text { side), laptop }\end{array}$ \\
\hline A4 & Carl & $2008-10-08$ & $\begin{array}{l}\text { Photo. Workspace, including } \\
\text { sticky notes, laptop, reports }\end{array}$ \\
\hline A5 & Carl & $2008-10-15$ & $\begin{array}{l}\text { Photo. Prize for teamwork, Carl } \\
\text { and Luis }\end{array}$ \\
\hline A6 & $\mathrm{N} / \mathrm{A}$ & $2008-10-15$ & $\begin{array}{l}\text { Photo. Three posters depicting } \\
\text { company's core values }\end{array}$ \\
\hline A7 & $\mathrm{N} / \mathrm{A}$ & $2008-10-15$ & $\begin{array}{l}\text { Photo. Poster for core value I: } \\
\text { Cooperation. Luis selected } \\
\text { this one }\end{array}$ \\
\hline A8 & $\mathrm{N} / \mathrm{A}$ & $2008-10-15$ & $\begin{array}{l}\text { Photo. Poster for accountability. } \\
\text { Daria and Stacy selected this } \\
\text { one }\end{array}$ \\
\hline A9 & $\mathrm{N} / \mathrm{A}$ & $2008-10-15$ & $\begin{array}{l}\text { Photo. Poster for Leadership. } \\
\text { Carl selected this one }\end{array}$ \\
\hline AlO & N/A & 2008-09-03 & $\begin{array}{l}\text { Document. Semoptco card } \\
\text { obtained from front desk }\end{array}$ \\
\hline All & $\mathrm{N} / \mathrm{A}$ & $2008-09-03$ & $\begin{array}{l}\text { Document."Competitive } \\
\text { Marketing" sheet."Why } \\
\text { Semoptco?" Obtained from } \\
\text { front desk }\end{array}$ \\
\hline $\mathrm{A} 12$ & $\mathrm{~N} / \mathrm{A}$ & 2008-09-03 & $\begin{array}{l}\text { Document. "Competitive } \\
\text { Marketing: Pay-Per- } \\
\text { Click Search Campaign } \\
\text { Management" sheet. Obtained } \\
\text { from front desk }\end{array}$ \\
\hline $\mathrm{Al} 3$ & $\mathrm{~N} / \mathrm{A}$ & $2008-09-03$ & $\begin{array}{l}\text { Document. "Competitive } \\
\text { Marketing: Search Engine } \\
\text { Optimization Campaign } \\
\text { Management" sheet. Obtained } \\
\text { from front desk }\end{array}$ \\
\hline
\end{tabular}

(continued) 


\section{Appendix E. (continued)}

\begin{tabular}{|c|c|c|c|}
\hline Artifact number & Participant & Date collected & Artifact description \\
\hline $\mathrm{Al} 4$ & N/A & $2008-09-03$ & $\begin{array}{l}\text { Document. “Competitive } \\
\text { Marketing:Web site } \\
\text { Effectiveness Strategy and } \\
\text { Consulting” sheet. Obtained } \\
\text { from front desk }\end{array}$ \\
\hline Al5 & Stacy & $2008-09-24$ & $\begin{array}{l}\text { Document."Natural search } \\
\text { services for <client>." List } \\
\text { of services and deliverables } \\
\text { by date, with deliverables } \\
\text { from Semoptco and client } \\
\text { differentiated }\end{array}$ \\
\hline Al6 & Stacy & $2008-09-24$ & $\begin{array}{l}\text { Document. "Paid Search } \\
\text { Services for <client name>." } \\
\text { List of deliverables by } \\
\text { date, with deliverables } \\
\text { from Semoptco and client } \\
\text { differentiated by color }\end{array}$ \\
\hline Al7 & Daria & $2008-09-24$ & $\begin{array}{l}\text { Document. Personal, not } \\
\text { shared. Built in Excel. Checks } \\
\text { off with red pen }\end{array}$ \\
\hline Al8 & Daria & $2008-09-24$ & $\begin{array}{l}\text { Document. "Semoptco } \\
\text { Process and Documents } \\
\text { Summary." Details process } \\
\text { and documents for campaign } \\
\text { launch (project) and campaign } \\
\text { maintenance (cyclical). The } \\
\text { launch echoes the steps in } \\
\text { artifacts I5 and I6. Bottom } \\
\text { right corner says "[Daria's } \\
\text { initials] 2/28/08" }\end{array}$ \\
\hline Al9 & Luis & $2008-10-15$ & $\begin{array}{l}\text { Document. “Natural Search } \\
\text { Progress Report Prepared for } \\
\text {... Sanitized report for Tier I } \\
\text { client. 18pp }\end{array}$ \\
\hline $\mathrm{A} 20$ & Luis & $2008-10-15$ & $\begin{array}{l}\text { Document. “Natural Search } \\
\text { Progress Report Prepared for } \\
\text {.." Sanitized report for Tier } 2 \\
\text { client. 18pp }\end{array}$ \\
\hline
\end{tabular}




\section{Appendix E. (continued)}

\begin{tabular}{|c|c|c|c|}
\hline Artifact number & Participant & Date collected & Artifact description \\
\hline $\mathrm{A} 2 \mathrm{I}$ & $\mathrm{N} / \mathrm{A}$ & $2008-09-15$ & $\begin{array}{l}\text { Document. White paper on } \\
\text { social marketing practices }\end{array}$ \\
\hline $\mathrm{A} 22$ & Luis & $2008-10-22$ & $\begin{array}{l}\text { Photo. New workspace, left } \\
\text { side }\end{array}$ \\
\hline $\mathrm{A} 23$ & Luis & $2008-10-22$ & $\begin{array}{l}\text { Photo. New workspace, right } \\
\text { side }\end{array}$ \\
\hline $\mathrm{A} 24$ & $\mathrm{~N} / \mathrm{A}$ & $2008-10-22$ & $\begin{array}{l}\text { Photo. Communal calendar for } \\
\text { October }\end{array}$ \\
\hline $\mathrm{A} 25$ & $\mathrm{~N} / \mathrm{A}$ & $2008-10-22$ & Photo. Calendars for Oct-Dec \\
\hline A26 & Daria & $2008-10-29$ & $\begin{array}{l}\text { Photo. Competition books } \\
\text { at right side of Daria's } \\
\text { cubicle. She recently took a } \\
\text { management position }\end{array}$ \\
\hline A27 & Daria & $2008-10-29$ & $\begin{array}{l}\text { Photo. Conference room with } \\
\text { whiteboard }\end{array}$ \\
\hline A28 & Daria & $2008-10-29$ & $\begin{array}{l}\text { Photo. Conference room, with } \\
\text { view of table and chairs }\end{array}$ \\
\hline A29 & Daria & $2008-10-29$ & $\begin{array}{l}\text { Photo. Management books at } \\
\text { left side of Daria's cubicle. She } \\
\text { recently took a management } \\
\text { position. }\end{array}$ \\
\hline $\mathrm{A} 30$ & Daria & $2008-10-29$ & $\begin{array}{l}\text { Photo. Left side of Daria's } \\
\text { cubicle with books, notepads, } \\
\text { laptop }\end{array}$ \\
\hline A3I & Daria & $2008-10-29$ & $\begin{array}{l}\text { Photo. Right side of Daria's } \\
\text { cubicle, with competition } \\
\text { books }\end{array}$ \\
\hline A32 & Stacy & $2008-10-29$ & $\begin{array}{c}\text { Photo. "Word of the Day" on a } \\
\text { whiteboard in Stacy's office }\end{array}$ \\
\hline A33 & Stacy & $2008-10-29$ & $\begin{array}{l}\text { Photo. Left side of desk. } \\
\text { Account managers have desks } \\
\text { facing the center of the room, } \\
\text { so they can all see and talk } \\
\text { with each other. A window } \\
\text { lets in natural light }\end{array}$ \\
\hline $\mathrm{A} 34$ & Stacy & $2008-10-29$ & $\begin{array}{l}\text { Photo. From behind the desk. } \\
\text { Laptop, spirals left and right, } \\
\text { reports, sticky notes }\end{array}$ \\
\hline
\end{tabular}




\section{Declaration of Conflicting Interests}

The author(s) declared no potential conflicts of interest with respect to the authorship

and/or publication of this article.

\section{Funding}

The author(s) received no financial support for the research and/or authorship of this

article.

\section{Note}

1. "Semoptco," participant names, and the analytical system "BRILLIANCE" are pseudonyms.

\section{References}

Anonymous. (2009). Search engine optimization. Wikipedia. Retrieved July 21, 2010, from http://en.wikipedia.org/wiki/Search_engine_optimization Bazerman, C. (1988). Shaping written knowledge. Madison: University of Wisconsin

Press.

Callon, M., Lascoumes, P., \& Barthe, Y. (2009). Acting in an uncertain world. Cambridge, MA: MIT Press.

Castells, M. (2003). The Internet galaxy. New York: Oxford University Press. Corbin, J., \& Strauss, A. C. (2008). Basics of qualitative research (3rd ed). Thousand Oaks, CA: Sage.

Devitt, A. J. (1991). Intertextuality in tax accounting: Generic, referential, and functional.

In J. G. Bazerman, Charles, \& Paradis (Eds.), Textual dynamics of the professions (pp. 336-357). Madison: University of Wisconsin Press. Duncan, W. R. (1996). A guide to the project management body of knowledge (1st ed.).

Newton Square, PA: Project Management Institute.

Engeström, Y. (2008). From teams to knots. New York: Cambridge University Press.

Granovetter, M. (1973). The strength of weak ties. American Journal of Sociology, $78,1360-1380$.

Gygi, K., \& Zachry, M. (2010). Productive tensions and the regulatory work of genres 
in the development of an engineering communication workshop in a transnational corporation. Journal of Business and Technical Communication, 24, 358-381. Killoran, J. B. (2009). Targeting an audience of robots: Search engines and the marketing of technical communication business Websites. IEEE Transactions on Professional Communication, 52, 254-271.

Miles, M. B., \& Huberman, A. M. (1994). Qualitative data analysis. Thousand Oaks, CA: Sage.

Miller, C. R. (1984). Genre as social action. Quarterly Journal of Speech, 70, 151167.

Mirel, B. (1996). Writing and database technology: Extending the definition of writing in the workplace. In P. Sullivan \& J. Dautermann (Eds.), Electronic literacies in the workplace (pp. 91-112). Urbana, IL: National Council of Teachers of English. Propen, A. D., \& Schuster, M. L. (2010). Understanding genre through the lens of advocacy: The rhetorical work of the Victim Impact Statement. Written Communication, 27(1), 3-35.

Russell, D. R. (1997a). Rethinking genre in school and society: An activity theory analysis. Written Communication, 14, 504-554.

Russell, D. R. (1997b). Writing and genre in higher education and workplaces: A review of studies that use cultural-historispincal activity theory. Mind, Culture, and Activity, 4, 224-237.

Russell, D. R. (2009). Uses of activity theory in written communication research. In

A. Sannino, H. Daniels, \& K. D. Gutierrez (Eds.), Learning and expanding with activity theory (pp. 40-52). New York: Cambridge University Press. Russell, D. R. (2010). Writing in multiple contexts: Vygotskian CHAT meets the phenomenology of genre. In C. Bazerman, R. Krut, K. Lunsford, S. McLeod, S. Null, P. Rogers, et al., (Eds.), Traditions of writing research (pp. 353-364). New York: Routledge. Schryer, C. F. (1993). Records as genre. Written Communication, 10, 200-234. Schryer, C. F., Afros, E., Mian, M., Spafford, M., \& Lingard, L. (2009). The trial of

the expert witness: Negotiating credibility in child abuse correspondence. Written Communication, 26, 215-246. Schryer, C. F., Lingard, L., \& Spafford, M. 